\title{
Performance of Japanese Overseas Subsidiaries: The Effects of Entry Mode and Ownership Advantages
}

\author{
Pimonwan SIRIPAISALPIPAT ${ }^{*}$ and Yasuo HOSHINO** \\ (University of Tsukuba)
}

\begin{abstract}
Performance of foreign subsidiaries of multinational enterprises (MNEs) is influenced by several factors. This study proposes that ownership advantages and entry mode choice of MNEs have influence on performance of their directly owned subsidiaries overseas. We investigate performance difference between the two FDI modes frequently used for entering to less-developed countries (LDCs), namely, international joint venture and greenfield venture. Ownership advantages of MNEs are hypothesized to be positively associated with subsidiary performance as those advantages are transferable from a parent firm to a subsidiary level. An empirical test based on a sample of 190 Japanese directly-owned subsidiaries located in Thailand provides supporting evidence.
\end{abstract}

\section{INTRODUCTION}

A multinational enterprise (MNE) invests overseas since it realizes the advantages of international market expansion and/or international production. The total value of Japanese outwardinvestment places Japan among the leading outward-investing countries in the world. Japanese MNEs engage in foreign direct investment (FDI) for two reasons; one is market orientation, and the other is factor orientation. The latter one is the key reason for Japanese direct investment in less developing countries (LDCs). Being attracted by the location advantages, many Japanese MNEs transplant their productions of intermediate products and build the regional networks of vertical integration of value-adding activities in several LDCs.

Performance of FDI activities is influenced by several factors. This study aims to explore some

* Pimonwan Siripaisalpipat, Doctoral student of Management Sciences and Engineering, Doctoral Program in Policy and Planning Sciences, University of Tsukuba, Japan.

** Yasuo Hoshino, Professor of Quantitative Finance and Management, Institute of Policy and Planning Sciences, University of Tsukuba, Japan. factors which affect performance of Japanese FDI in LDCs. The influencing factors in the scope of this study include two areas; ownership advantages of Japanese parent firms and their entry mode choice for FDI activities.

The previous research on entry mode performance of Japanese overseas investment found evidence of performance difference between ownership-based entry modes, showing that greenfield venture has higher performance profile than international joint venture and acquisition ( $\mathrm{Li}$ and Guisinger, 1991; Nitsch, Beamish, and Makino, 1996; Woodcock, Beamish, and Makino, 1994). Nevertheless, the empirical tests are limited to the samples of Japanese subsidiaries in developed countries.

This study investigates performance of entry modes which Japanese firms used to established directly-owned subsidiaries in LDCs. Further, this study also attempts to examine the effect of ownership advantages of a Japanese parent on performance of its subsidiary. The empirical test is conducted using the sample of 190 Japanese manufacturing subsidiaries in Thailand ${ }^{1)}$.

\section{BACKGROUND AND LITERATURE REVIEWS}

Possession of superior advantages drives an 
enterprise to engage in foreign direct investment (FDI). Firms which own specific advantages in a particular activity find it economic to exploit these advantages by expanding internationally (Hymer, 1976). Firms with specific advantages find it in their interests to locate (part of) their production overseas where the host country offers certain location-specific advantages (Dunning, 1981), and to internalize the value-adding activities of international production where structural and/or transactional market imperfections exist (Buckley and Casson, 1976; Dunning, 1981; Hymer, 1976; Kindleberger, 1969).

The degree of internalization, or the level of ownership in a subsidiary, usually depends on the parent firm's need for control over that subsidiary as well as the parent firm's resource availability. Different entry modes provide a firm with different levels of control (Caves, 1982; Davidson, 1982) and resource commitment (Vernon, 1983). A firm that possesses vital resources and is unwilling to share (transfer) them with other firms may prefer the wholly-owned mode, in which a parent firm has sole control over that subsidiary. In addition, resource transfer is internal to the firm, reducing the possible transaction costs of external market. In contrast, a firm which lacks necessary resources will be better off by employing a cooperative form of entry mode, namely an international joint venture. In joint venture, a foreign parent firm also has (some) control over the operation and decision-making process of a local firm. (Buckley and Casson, 1985). Joint venture facilitates inter-firm learning and transfer of intangible assets (Kogut, 1988), while reducing incentives for opportunism by creating interdependence between the transacting parties (Hennart, 1988). In addition, in some countries, usually in less developed countries, the host country governments restrict the level of foreign ownership in local firms due to the need for foreign contributions in technology transfer and skill development to the local partnering firm. This is one reason why the joint venture mode is the predominant mode used by MNEs investing in LDCs.

Thai government has also enacted some restrictions on foreign ownership in a local entity. In the case of manufacturing sector, share ownership by foreign investor is restricted to not over than $49 \%$ if the subsidiary's production is at least $50 \%$ for the domestic market. Where at least $50 \%$ is for export, foreign investor may hold a majority or total of the shares. However, such restrictions are relaxed for subsidiaries which directly involve in technological development.

\section{HYPOTHESIS DEVELOPMENT}

\section{Entry Mode versus Performance \\ Entry mode and performance}

Normally, a firm which invests abroad has the disadvantage of being foreign in the host country (Hymer, 1976). Although LDCs have a number of location advantages attractive to foreign firms, they are usually characterized by more government restrictions imposed to foreign investors and more uncertainty. In such circumstance, cost of full control would be higher, relative to that in less restricted, less risky markets.

Hypothesis 1: The international joint venture mode will, on average, perform better than the greenfield mode in Thailand.

\section{Share Ownership and performance}

The evidence concerning the relationship between share ownership and performance is ambiguous. While some studies (such as Killing, 1983) found that dominant-owned ventures perform better, Beamish (1985) and Tomlinson (1970) found that balanced control ventures obtained higher performance outcome. If everything is constant, the cooperative relationship will produce synergy effects derived from the input efforts of two (or more) parties. Equal sharing of interest between foreign firm and the local partners will lead to greater contribution from both sides (Tomlinson, 1970), and thereby generate greater benefits to the subsidiary which is the output of their cooperative efforts. In contrast, joint ventures with dominant foreign parent are usually managed like wholly-owned subsidiaries in which 
Performance of Japanese Overseas Subsidiaries:

key decisions are made by the dominant parent (Killing, 1983). Consequently, dominant foreign parent might regard the local partner's contribution as unimportant. Beamish (1987) suggested that the lack of need for a partner would result in poor performance in a joint venture. Since joint venture operation incurs additional costs (such as communication costs), using joint venture form of organization is not an efficient use of resources when a contribution from the partner is not sought.

Hypothesis 2: The balanced-ownership joint venture will, on average, perform better than the majority-owned joint venture or the minority-owned joint venture.

\section{Ownership Advantages versus Performance}

Ownership advantages refer to the ownership of specific assets, particularly intangible assets, and capabilities which bring a superior competitive position to the possessing firm. Such asset power leads to the competitive advantages and thus a firm's success in the market it serves. Ownership advantages of a MNE are expected to have positive influence on performance of the subsidiary, since those advantages are usually transferable from a parent firm to a subsidiary level.

Ownership advantages can be classified into 2 subgroups: transaction-specific advantages and international management capabilities. Transaction-specific advantages are the key resources, which have been accumulated inside the firm over the time it has been operated, and which is necessary to compete efficiently in a certain business line or a certain industry. Differentiated product, advanced technology and specialized knowledge or know-how are some examples of transactionspecific advantages. International management capabilities are the advantages obtained from the increasing experience in international operations. As a firm expands the operation overseas, a firm has learned more about how to cope with the different environments in terms of the economic, political and legal systems, as well as the cultural distances. The international experience and country experience are the stocks of knowledge which a newly established subsidiary can apply into its own operational process.

Hypothesis 3: The transaction-specific advantages of the foreign parent are positively associated with the subsidiary performance.

Hypothesis 4: The international management capabilities of the foreign parent are positively associated with the subsidiary performance.

\section{METHODOLOGY}

\section{Scope of the Study}

The study focuses on the Japanese manufacturing MNEs which established new entities in manufacturing sector in Thailand. The modes of entry are restricted to new entities which initiate investments in new facilities, namely international joint venture (IJV) and greenfield investment (GF), to control for the effect of the prior advantages inherit in subsidiaries as merger or acquisition mode would have been employed. To examine the effect of share ownership, the entries are further classified into four types of share ownership; minority-owned joint venture, balancedownership joint venture, majority-owned joint venture, and greenfield venture.

\section{Sources of Data}

The measurement of subsidiary's performance, the dependent variable in this study, is obtained from financial ratio-based performance reported in the Million Baht Business Information Thailand (the profiles of 6000 leading companies in Thailand), 1995. The rate of return on asset invested ( $R O A$ ) in a subsidiary is employed to measure performance in term of profitability.

The classification of entry modes and ownership types is based on the data of the Toyo Keizai, Japanese Overseas Investments, listed by countries, 1995. The database covers all Japanese 
overseas investments undertaken by Japanese firms listed on the Japan stock exchanges (Tokyo, Osaka, and Nagoya) as well as by major unlisted Japanese firms. Based on share ownership data reported in this database, the subsidiaries are categorized into two entry modes, as well as four ownership types.

The data for ownership advantages of parent firms are obtained from two Japanese databases, using the year 1994 as the base year. The data for transaction-specific advantages are derived from Nikkei Zaimu database, and Nikkei Kaisha Nenkan when unavailable from the former source. The data for international management capabilities are obtained from Toyo Keizai, Japanese Overseas Investments, listed by firms.

Since newly-established subsidiaries require some time to learn for establishing themselves, performance during the start-up period is not yet stable. The study of Woodcock, Beamish, and Makino (1994), using piece-wise linear regression with a breakpoint, found that performance of subsidiaries tended to stabilize two years after entry. Following this result, the subsidiaries which the age of establishment was less than two years at the time of the data collection have been excluded.

\section{Data Selection and Sample}

From the census of subsidiaries recorded by Toyo Keizai, those with performance data available were selected. Ownership share by Japanese firms was computed, with shares of multiple Japanese investors aggregated and indirect shares due to Japanese ownership of local parent firm are also added to the Japanese share. Although many studies restrict attention to subsidiaries with a single foreign parent, we accept multiple partners. Partly this is due to the prevalence of multiple foreign partners in our data. However, since this behavior evidently reflects the "keiretsu" relations of Japanese firms, this should mitigate conflicts of interest. Thereby considering this share as determining degree of control by the Japanese partner seems reasonable. Beamish's (1985) study of joint venture performance in LDCs also suggests that there is no performance difference between joint ventures with two partners, or more than two partners.

As a result, the sample of 190 cases was used for the analysis of mode performance. In order to examine the effect of ownership advantages on performance, we associate performance with ownership advantages of a dominant Japanese shareholder, which we take as the (main) Japanese parent firm. For the regression analysis, the sample was reduced to 105 cases according to availability of data for the Japanese parent firms.

\section{Model Development}

The study attempts to assess how ownership advantages and entry mode choice of a foreign parent firm affect performance of its subsidiary. Performance of a subsidiary is explained by the following model.

Performance $=f \quad$ [Parent's TransactionSpecific Advantages, Parent's International Management Capabilities, and Entry Mode]

The model can be expressed as

$$
Y=\beta_{0}+\beta_{1} X_{1}+\beta_{2} X_{2}+\ldots+\varepsilon,
$$

where $\mathrm{Y}$ is the rate of return on assets invested, $\mathrm{X}_{\mathrm{i}}$ is the independent variables, and $\beta_{i}$ is the coefficients of the independent variables. $\beta_{0}$ is the constant and $\varepsilon$ is the disturbance term.

\section{Measures of the Independent Variables \\ Entry Mode and Share Ownership}

FDI entries with at least 95 percent Japanese ownership are categorized as greenfield investment (GF); and as international joint venture (IJV) if otherwise (Anderson and Gatignon, 1986). In the model, entry mode (MODE) is captured by a dummy variable equal to zero for IJV, and one for GF.

The classification of IJV is based on the Japanese ownership level; lower than 49 percent for minority IJV, between 49 to 51 percent for balanced-ownership IJV, and higher than 51 percent for majority IJV respectively ${ }^{2)}$. Ownership type is captured by dummy variables IJVI 
and IJV2; IJV1 equal to one if the entries are balanced-ownership IJV and zero otherwise, IJV2 equal to one if the entries are majority IJV and zero otherwise.

\section{Ownership Advantages}

Transaction-specific advantages are measured by several proxies. First, the parent's sales size in logarithm form (SIZE) is used as a proxy for the asset power of a parent firm. Firms with larger size usually possess greater potential to make intensive investments in advanced technology and product innovation.

Brand, image and reputation are those kinds of product related intangible assets of a firm. The degree of advertising intensity (ADINTEN) may imply the level of value a parent firm places on product differentiation.

The major source of specialized knowledge and technology is a firm's contribution in research and development. The parent's R\&D intensity ( RDINTEN) is also used as a proxy for intangible assets of a firm.

Managerial know-how is the other type of intangible assets, which helps enhance efficiency and profitability in an operation. Managerial knowhow is measured by the parent's capital turnover rate for efficiency (EFFICNT) and rate of return on sales of productive outputs for profitability (PROFIT).

As for international management capabilities, international experience (INTER) is measured by the number of overall subsidiaries the parent firm established in IJV and greenfield modes overseas. Local experience (LOCAL) is the stock of all experience learned from operating every FDI subsidiary in the host country. LOCAL is measured based on the combined length of time (years) that the parent has been operating each of the manufacturing IJV or greenfield subsidiaries in the host country. However, the advantage of parent's prior local experience inclines to decrease as a subsidiary accumulates more operating experience. Hence, subsidiary experience (SUBEXP), or length of time of operation, together with interaction between LOCAL and SUBEXP are added into the regression model.

\section{RESULTS OF THE EMPIRICAL ANALYSIS}

\section{Mode Performance Analysis}

The relationship between entry mode and performance, as well as between ownership level and performance were examined. Performance of the two entry modes and four ownership types, together with the results of the statistical tests, are shown in Table 1 and Table 2 respectively.

Table 1 Performance Difference between Two Entry Modes

\begin{tabular}{|c|c|c|c|}
\hline \multirow{2}{*}{ Entry Modes } & \multicolumn{2}{|c|}{ Performance } & \multirow{2}{*}{$\begin{array}{l}\text { No. of } \\
\text { Cases }\end{array}$} \\
\hline & Mean & Std. Dev. & \\
\hline IJV & 9.29 & 9.46 & 158 \\
\hline Greenfield venture & 6.80 & 7.36 & 32 \\
\hline Totals & 8.88 & 9.43 & 190 \\
\hline
\end{tabular}

$\begin{array}{ll}\text { Tests } & \text { Value (Significant) } \\ \text { ANOVA } & 1.866(0.174) \\ \text { Association (Eta) } & 0.099\end{array}$

Table 2 Performance Difference among Four Types of Share Ownership

\begin{tabular}{|c|c|c|c|}
\hline \multicolumn{4}{|l|}{ The Year 1994} \\
\hline \multirow{2}{*}{ Ownership Types } & \multicolumn{2}{|c|}{ Performance } & \multirow{2}{*}{$\begin{array}{r}\text { No. of } \\
\text { Cases }\end{array}$} \\
\hline & Mean & Std. Dev. & \\
\hline Minority IJV & 8.75 & 9.73 & 57 \\
\hline $\begin{array}{l}\text { Balanced- } \\
\text { ownership IJV }\end{array}$ & 12.54 & 9.61 & 43 \\
\hline Majority IJV & 7.42 & 9.47 & 58 \\
\hline Greenfield venture & 6.80 & 7.36 & 32 \\
\hline Totals & 8.88 & 9.43 & 190 \\
\hline \multicolumn{4}{|c|}{ Tests $\quad$ Value (Significant) } \\
\hline ANOVA & 3.25 & $(0.023)$ & \\
\hline Association (Eta) & 0.22 & & \\
\hline \multicolumn{4}{|c|}{ Post hoc test for each paired group } \\
\hline $\mathrm{p}<0.01: \quad$ BL- & $\begin{array}{l}\text { V vs } G F \\
\text { V vs } M J\end{array}$ & & \\
\hline $\mathrm{p}<0.1:$ & $\mathrm{V}$ vs $\mathrm{MI}$ & & \\
\hline
\end{tabular}

Although performance of the international joint venture (IJV) is higher than the greenfield venture (GF), there is no significant performance differ- 
ence between them. When the subsidiaries are classified into 4 types of share ownership, the result shows that balanced-ownership IJV outperforms the other three ownership types. Performance difference within ownership types is significant at 0.023 level. When a post hoc test is applied to each paired group, performance of balancedownership IJV is significantly higher than minority IJV, majority IJV, and greenfield venture. The results support the view that equally-controlled $\mathrm{IJV}$ is more effective for joint venture formation. While balanced-ownership IJV is, on average, considerably profitable than greenfield venture, the profitability in dominant IJV does not much differ from that in greenfield venture. In dominant IJV, local partners - even if they have passive role - are involved in the venture's operations, though their contribution might be only little. This results in an efficiency cost to the venture without a corresponding benefit (Beamish, 1987).

\section{Industry Effect}

Performance level of firms in one industry may be different from the other industries. Each industry differs in several aspects such as the required scale of investment, the nature of market and competition, and the stage in the international product life cycle in a particular country; thus allowing different rate of return a firm can exploit. Consequently, the industry effect has been investigated to see whether there are the significant differences in performance across industries. The industries are classified into seven groups, based on the data of industry classification in the Million Baht Business Information Thailand. The industry groups and the corresponding summarized statistics are shown in Table 3 .

The result of ANOVA test for performance differences between groups obtains F-value of 2.74, which is significant at 0.014 level. The industry factor obviously affects the profitability of subsidiaries. This requires the adjustment of the industry effect on subsidiaries' rate of return, ROA.

The relationship between ownership types and performance is reexamined for each industry, in
Table 3 Performance Difference across Industry Groups

\begin{tabular}{|c|c|c|}
\hline Industry Group & & $\begin{array}{c}\text { Perform- } \\
\text { ance (ROA) }\end{array}$ \\
\hline \multirow[t]{3}{*}{ Group 1 : Food and drinks } & Mean & 9.70 \\
\hline & Std. Dev. & 10.91 \\
\hline & $\mathrm{N}$ & 13 \\
\hline \multirow{3}{*}{$\begin{array}{l}\text { Group } 2 \text { : Textiles, fabric } \\
\text { and leather product }\end{array}$} & Mean & 4.86 \\
\hline & Std. Dev. & 8.26 \\
\hline & $\mathrm{N}$ & 22 \\
\hline \multirow{3}{*}{$\begin{array}{l}\text { Group } 3 \text { : Wood products, } \\
\text { furniture, pottery, glass, } \\
\text { and clay }\end{array}$} & Mean & 2.43 \\
\hline & Std. Dev. & 6.81 \\
\hline & $\mathrm{N}$ & 8 \\
\hline \multirow{3}{*}{$\begin{array}{l}\text { Group } 4 \text { : Chemical } \\
\text { products, rubbers, and } \\
\text { plastics }\end{array}$} & Mean & 9.83 \\
\hline & Std. Dev. & 8.73 \\
\hline & $\mathrm{N}$ & 39 \\
\hline \multirow{3}{*}{$\begin{array}{l}\text { Group } 5 \text { : Electrical and } \\
\text { Electronics }\end{array}$} & Mean & 7.81 \\
\hline & Std. Dev. & 7.91 \\
\hline & $\mathrm{N}$ & 40 \\
\hline \multirow[t]{3}{*}{ Group 6 : Transportation } & Mean & 13.78 \\
\hline & Std. Dev. & 12.48 \\
\hline & $\mathrm{N}$ & 24 \\
\hline \multirow{3}{*}{$\begin{array}{l}\text { Group } 7 \text { : Metal products, } \\
\text { engine, machinery, and } \\
\text { other }\end{array}$} & Mean & 9.35 \\
\hline & Std. Dev. & 8.69 \\
\hline & $\mathrm{N}$ & 44 \\
\hline \multirow[t]{3}{*}{ Total } & Mean & 8.88 \\
\hline & Std. Dev. & 9.40 \\
\hline & $\mathrm{N}$ & 190 \\
\hline
\end{tabular}

ANOVA Tests for Mean Differences :

F Value (significant)

$2.74(\mathrm{p}=0.014)$

order to see the difference in mode performance in different industries. Table 4 shows the profitability of each ownership type in each industry group. The result shows that balanced-ownership IJV outperforms other ownership types in three industries, while minority IJV performs better in the other three industries. However, no significant difference is found at $5 \%$ level in any industries. In an industry level, due to the small size of subsamples, the trend for performance difference among ownership types could not be effectively inferred; though there is a significant performance difference in an aggregated industry level. 
Performance of Japanese Overseas Subsidiaries:

Table 4 Performance Difference among Ownership Types by Industries

\begin{tabular}{l|lcccc|c}
\hline \hline \multirow{2}{*}{ Industry Group } & \multicolumn{5}{|c|}{ Performance (ROA) } & F value \\
\cline { 2 - 6 } (sig.)
\end{tabular}

Note : 1) the statistical test for mean difference can not be obtained for Group 3, because of missing data for three ownership types.

\section{Univariate Analysis}

In the preliminary analysis, univariate regression model is fitted for each explanatory variable. The estimated coefficient, and the $t$ statistics of each independent variable are shown in Table 5 .

With ROA data, all ownership-advantage variables are positively associated with performance. Interaction term, LOCAL * SUBEXP, seems to add explanatory power to LOCAL, of which coefficient becomes more significant. The direction of relationship suggests that, the more a subsidiary acquires operating experience, the less incremental advantage it can earn from a parent's local experience.

The coefficient of MODE shows positive sign but it is not significant. When the model is fitted with three ownership type dummies, the coefficients show that balanced-ownership IJV tends to have higher performance than the other ownership types. Performance difference among minority IJV, majority IJV, and greenfield venture is very little.

\section{Regression Model}

Multivariate regression models are fitted to the ROA. Three models are examined: (1) model containing the effect of ownership advantages, (2) model containing the effect of ownership advantages, including industry adjustment, (3) model containing the effects of ownership advantages and ownership types ${ }^{3)}$.

\section{Effect of ownership advantages}

First, the combined effect of ownership advantage variables was examined. The result of the fitted model and corresponding statistical tests is shown as model 1 in Table 6.

In multivariate model, SIZE appears to have 
Table 5 Univariate Analysis for Performance Data

\begin{tabular}{|c|c|c|}
\hline \multirow[b]{2}{*}{ Independent Variables } & \multicolumn{2}{|r|}{ Effects on performance (ROA) } \\
\hline & $\begin{array}{l}\text { Hypothe- } \\
\text { sized sign }\end{array}$ & \\
\hline \multicolumn{3}{|l|}{ Ownership Advantages } \\
\hline SIZE & + & $\begin{array}{l}-11.326+0.751 \text { SIZE } \\
(0.731) \quad(1.273)\end{array}$ \\
\hline ADINTEN & + & $\begin{array}{l}7.992+0.342 \text { ADINTEN } \\
(8.844)(1.057)\end{array}$ \\
\hline RDINTEN & + & $\begin{array}{l}7,961+0.100 \text { RDINTEN } \\
(7,394) \quad(0.591)\end{array}$ \\
\hline EFFICNT & + & $\begin{array}{l}7.538+0.317 \text { EFFICNT } \\
(5.115) \quad(0.679)\end{array}$ \\
\hline PROFIT & + & $\begin{array}{l}7.638+0.515 \text { PROFIT } \\
(7.929) \quad(1.475)\end{array}$ \\
\hline INTER & + & $\begin{array}{l}5.429+0.156 \text { INTER }- \\
(4.578)(3.335)\end{array}$ \\
\hline LOCAL & + & $\begin{array}{l}7.155+0.0507 \text { LOCAL } \\
(5.204)(1.103)\end{array}$ \\
\hline SUBEXP & + & $\begin{array}{l}6.758+0.133 \text { SUBEXP } \\
(4.799) \quad(1.410)\end{array}$ \\
\hline LOCAL* SUBEXP & - & $\begin{array}{l}3.486+0.145 \text { LOCAL }^{*}+0.425 \text { SUBEXP } \\
(1.569) \quad(1.778) \\
-0.010 \text { LOCAL }^{*} \text { SUBEXP* } \\
(1.817)\end{array}$ \\
\hline \multicolumn{3}{|l|}{ Entry Mode } \\
\hline $\operatorname{MODE}(1=\mathrm{GF})$ & - & $\begin{array}{l}8.351+0.053 \mathrm{MODE} \\
(8.974) \quad(0.027)\end{array}$ \\
\hline \multicolumn{3}{|l|}{ Ownership Level } \\
\hline $\mathrm{IJV} 1(1=\mathrm{BL}-\mathrm{IJV})$ & + & $7.651+3.110 \mathrm{IJV} 1-0.085 \mathrm{IJV} 2+0.758 \mathrm{MODE}$ \\
\hline IJV $2(1=$ MJ-IJV $)$ & $?$ & $\begin{array}{llll}(5.125) & (1.280) & (0.040) & (0.312)\end{array}$ \\
\hline $\operatorname{MODE}(1=\mathrm{GF})$ & - & \\
\hline
\end{tabular}

Note : 1) Sample size is 105 cases.

2) t-statistics in parentheses; "significant at the $10 \%$ level, "significant at the $5 \%$ level, and significant at the $1 \%$ level.

significantly negative relationship with ROA, while all other ownership advantage variables have positive relationship. The reported model $\mathrm{R}^{2}$ is 0.23 and the model is significant at 0.003 level. This supports our $\mathrm{H} 1$ and $\mathrm{H} 2$ that parents' ownership advantages have positive influence on the profitability of their subsidiaries.

In order to adjust for the industry effect, six industry dummies are added into the model: IND1

\begin{abstract}
$=1$ for "food and drinks"; IND2 $=1$ for "textiles, fabric and leather product"; IND3 = 1 for "wood products, furniture, pottery, glass, and clay"; IND4 $=1$ for "chemical products, rubbers, and plastics"; IND6 = 1 for "transportation"; IND7 = 1 for "metal products, engine, machinery, and other" ${ }^{4)}$. The result of model containing ownership advantage variables and industry effect is shown as model 2 in Table 6 .
\end{abstract}


Performance of Japanese Overseas Subsidiaries:

Table 6 Regression Models for Performance Data

\begin{tabular}{|c|c|c|c|}
\hline & $\begin{array}{c}\text { Model 1 } \\
\text { O-Advantages } \\
(\mathrm{w} / \mathrm{o} \text { industry })\end{array}$ & $\begin{array}{c}\text { Model } 2 \\
\text { O-Advantages }\end{array}$ & $\begin{array}{c}\text { Model } 3 \\
\text { O-Advantages } \\
\text { and } \\
\text { Ownership Types }\end{array}$ \\
\hline Constant & $\begin{array}{l}46.227^{*} \\
(2.220)\end{array}$ & $\begin{array}{l}42.497^{*} \\
(2.037)\end{array}$ & $\begin{array}{l}43.792^{*} \\
(1.913)\end{array}$ \\
\hline SIZE & $\begin{array}{l}-1.945^{* *} \\
(2.294)\end{array}$ & $\begin{array}{l}-1.815^{*} \\
(2.123)\end{array}$ & $\begin{array}{c}-1.866^{*} \\
(2.038)\end{array}$ \\
\hline ADINTEN & $\begin{array}{c}0.280 \\
(0.846)\end{array}$ & $\begin{array}{c}0.233 \\
(0.708)\end{array}$ & $\begin{array}{c}0.275 \\
(0.807)\end{array}$ \\
\hline RDINTEN & $\begin{array}{c}0.015 \\
(0.086)\end{array}$ & $\begin{array}{c}0.038 \\
(0.224)\end{array}$ & $\begin{array}{c}0.068 \\
(0.389)\end{array}$ \\
\hline EFFICNT & $\begin{array}{l}1.137^{*} \\
(2.258)\end{array}$ & $\begin{array}{l}1.227^{*} \\
(2.367)\end{array}$ & $\begin{array}{l}1.115^{* *} \\
(2.112)\end{array}$ \\
\hline PROFIT & $\begin{array}{c}0.543 \\
(1.360)\end{array}$ & $\begin{array}{c}0.494 \\
(1.241)\end{array}$ & $\begin{array}{c}0.481 \\
(1.199)\end{array}$ \\
\hline INTER & $\begin{array}{c}0.281 \\
(3.849)\end{array}$ & $\begin{array}{c}0.231 * \\
(2.993)\end{array}$ & $\begin{array}{l}0.233^{* *} \\
(2.864)\end{array}$ \\
\hline LOCAL & $\begin{array}{c}0.086 \\
(1.004)\end{array}$ & $\begin{array}{c}0.061 \\
(0.716)\end{array}$ & $\begin{array}{c}0.069 \\
(0.806)\end{array}$ \\
\hline SUBEXP & $\begin{array}{l}0.462 \\
(2.372)\end{array}$ & $\begin{array}{c}0.447^{*} \\
(2.334)\end{array}$ & $\begin{array}{c}0.442 * \\
(2.263)\end{array}$ \\
\hline LOCAL* SUBEXP & $\begin{array}{c}-0.011^{*} \\
(1.882)\end{array}$ & $\begin{array}{r}-0.007 \\
(1.210)\end{array}$ & $\begin{array}{r}-0.007 \\
(1.246)\end{array}$ \\
\hline IND 1 & & $\begin{array}{r}-0.263 \\
(0.073)\end{array}$ & $\begin{array}{r}-1.032 \\
(0.280)\end{array}$ \\
\hline IND 2 & & $\begin{array}{r}-6.074^{*} \\
(1.900)\end{array}$ & $\begin{array}{c}-6.743^{*} \\
(2.046)\end{array}$ \\
\hline IND 3 & & $\begin{array}{r}-3.092 \\
(0.519)\end{array}$ & $\begin{array}{r}-3.025 \\
(0.614)\end{array}$ \\
\hline IND 4 & & $\begin{array}{c}0.734 \\
(0.313)\end{array}$ & $\begin{array}{c}0.170 \\
(0.069)\end{array}$ \\
\hline IND 6 & & $\begin{array}{c}0.206 \\
(0.068)\end{array}$ & $\begin{array}{r}-0.696 \\
(0.222)\end{array}$ \\
\hline IND 7 & & $\begin{array}{l}4.523^{*} \\
(2.057)\end{array}$ & $\begin{array}{c}4.311^{*} \\
(1.912)\end{array}$ \\
\hline MODE & & & $\begin{array}{r}-1.219 \\
(0.452)\end{array}$ \\
\hline IJV 1 & & & $\begin{array}{c}2.556 \\
(1.093)\end{array}$ \\
\hline IJV 2 & & & $\begin{array}{c}0.632 \\
(0.314) \\
\end{array}$ \\
\hline Number of Cases & 105 & 105 & 105 \\
\hline F-statistics & 3.084 & 2.819 & 2.445 \\
\hline Model significant & 0.003 & 0.001 & 0.003 \\
\hline $\mathrm{R}^{2}$ & 0.226 & 0.322 & 0.339 \\
\hline Adjusted $\mathrm{R}^{2}$ & 0.153 & 0.208 & 0.200 \\
\hline
\end{tabular}

Note: 1 ) t-statistics in parentheses; "significant at the $10 \%$ level, "significant at the $5 \%$ level, and significant at the $1 \%$ level.

2 ) O-advantages is an abbreviation for Ownership advantages. 
Similar to model 1, all ownership advantage variables, except SIZE, are positively associated with performance. As for industrial factor, IND1, IND2, and IND3 have lower rate of return than average, while IND 4, IND6 and IND7 have higher rate of return than average. Yet, only IND2 and IND7 are significant. After industry variables were added, $\mathrm{R}^{2}$ was improve from 0.23 to 0.32 , reflecting higher explanatory power of the new model with industry adjustment.

\section{Effects of ownership advantages and ownership types}

The effects of ownership advantages and ownership types, together with industrial factor, were examined. The result in model 3 of Table 6 shows that MODE $(\mathrm{GF}=1)$ inclines to be the least profitable, while IJV1 (BL-IJV=1) seems to have higher profitability than average about 2.6 point. However, none of ownership type variable is significant. The effects of ownership advantage variables and industry variables do not differ from those without ownership types, except IND6 which becomes negative. $R^{2}$ of model 3 was obtained the value of 0.34 , increasing slightly from the previous model. Though the sample for the empirical analysis in this study includes subsidiaries with both single and multiple Japanese parents, we tested the model by fitting the regression using sub-sample of single Japanese parent. According to the result (see Appendix 2), there seems to be no difference between the full sample and subsample.

\section{CONCLUSIONS}

The results of this study provide strong evidence for the important role of MNEs' ownership advantages in the operations of their overseas subsidiaries. The results of the empirical analyses suggest that the variables related to product differentiation, specialized technology, managerial knowhow, international experience, and country experience appear to have positive influences on the profitability of subsidiaries. Through the internalization process, the proprietary product and technology as well as the operational and international management know-how possessed by MNEs are transferred to their directly-owned foreign subsidiaries. Firm-specific intangible assets both in terms of transaction-specific assets and international management capabilities of Japanese MNEs lead to the competitiveness and the performance of their subsidiaries in foreign markets.

Firm size seems to be negatively associated with profitability. Previous research on corporate size and profit rates reveals that the profit rates of small firms are rather lower than those of middlesized firm, whereas larger-sized firms yield profit rates that are slightly lower but more stable than the profit rates of middle-sized firms. Although firm size can increase profitability significantly via market power, this might be offset by inefficiency caused by a degree of bureaucracy in many larger firms (see Shepherd, 1979). Further, largersized firms usually aim to maintain stable and long term growth, thus satisfy with moderate profit rates.

The mode performance analysis reveals that there exists the performance difference among different forms of organization. Being different from the evidence in developed countries, performance of greenfield venture tends to be lower than IJV, particularly balanced-ownership IJV. Balanced-ownership IJV appears to outperform other types of ownership, while performance of minority IJV and majority IJV do not differ that much. The insignificance of performance difference between aggregated IJV and greenfield venture implies that viewing all types of joint venture as common might not be appropriate. Different forms of joint venture differ in several aspects, including the distribution of control and the way the ventures are managed. In joint venture, equally shared control between foreign firm and the local partners can lead to greater contribution from both sides, and thereby to the profitability of the venture (Tomlinson, 1970).

Nevertheless, this study has some limitations. Firstly, the sample is limited to only FDI activities of MNEs of single nationality and those invested in one host country. This is partly 
because the financial performance data of foreign subsidiaries in many LDCs is very hard to obtain. Secondly, rate of return of subsidiary is merely an explicit measure of performance. In some cases, a firm accepts moderate to lower rate of return for some strategic reasons such as market share orientation, transfer pricing, and etc. Other meaningful performance measurement could be considered, including subjective performance indicators like management satisfaction on the operations.

\section{Notes:}

1. Thailand is the fourth largest Japanese investment recipients in the world, following The U.S., China, and Hong Kong. There are in total 1,289 Japanese subsidiaries in Thailand in the year 1996, reported in Toyo Keizai, Japanese Overseas Investments [Toyo Keizai (1997)].

2. In our sample, there exists a number of foreign subsidiaries of which foreign parents hold balance equity at 49 percent instead of 50 percent. This is because, in Thailand a foreign parent firm cannot hold share ownership larger than $49 \%$ of the total shares if the subsidiary sells more than $50 \%$ of outputs in domestic market.

3 . The descriptive statistics and the correlation matrix of variables in the regression model are shown in Appendix 1.

4. Because the performance mean of IND5 was closest to the performance mean of all industry combined, IND5 was omitted from the model. In other words, the performance of "electrical and electronics" is regarded as the industry average rate of return.

\section{References}

Anderson, E. and Gatignon, H. 1986 Modes of foreign Entry: Transaction Cost Analysis and Propositions. Journal of International Business Studies, 3, 1-26.

Beamish, P. W. 1985 The Characteristics of Joint Ventures in Developed and Developing Countries. Columbia Journal of World Business,
Fall,13-19.

Beamish, P. W. 1987 Joint Ventures in LDCs. Management International Review, 27, 23-37.

Buckley, P. J. and Casson, M. 1976 The Future of

The Multinational Enterprise. London: Macmillan.

Buckley, P. J. and Casson, M. 1985 The Economic Theory of The Multinational Enterprise. London: Macmillan.

Caves, R. 1982 Multinational Enterprise and Economic Analysis. New York: Cambridge University Press.

Davidson, W. 1982 Global Strategic Management. New York: John Wiley.

Dunning, J. H. 1981 International Production and the Multinational Enterprise. London: George Allen \& Unwin.

Hennart, J. F. 1988 A Transaction Costs Theory of Equity Joint Ventures. Strategic Management Journal, 9, 361-374.

Hymer, S. 1976 The International Operations of National Firms: A Study of Direct Foreign Investment. Cambridge: MIT Press. (Originally presented as Unpublished Doctoral Dissertation MIT, 1960)

International Business Research. 1995 Million Baht Business Information Thailand. Bangkok: International Business Research (Thailand) Co., Ltd.

Li, J. and S. Guisinger. 1991 Comparative Business Failures of Foreign-Controlled Firms in the United States. Journal of International Business Studies, 2, 209-224.

Killing, J. P. 1983 Strategies for Joint Venture Success. New York: Praeger.

Kindleberger, C. P. 1969 American Business Abroad: Six Lectures on Direct Investment. New Haven: Yale University Press.

Kogut, B. 1988 Joint Ventures : Theoretical and Empirical Perspectives. Strategic Management Journal, 9, 319-332.

Nihon Keizai Shinbunsha. 1995 Kaisha Nenkan (Annual Company Profiles). Tokyo: Nihon Keizai Shinbunsha.

Nihon Keizai Shinbunsha. Nikkei Zaimu Database. Tokyo: Nihon Keizai Shinbunsha. 
Nitsch, D., Beamish, P. W. and Makino, S. 1996 Entry Mode and Performance of Japanese FDI in Western Europe. Management International Review, 36, 27-43.

Shepherd, W. G. 1979 The Economics of Industrial Organization. London: Prentice-Hall International Inc.

Siripaisalpipat, P. and Hoshino, Y. Firm-Specific Advantages, Entry Modes, and Performance of Japanese FDI in Thailand. Japan and the World Economy (forthcoming).

Tomlinson, J. W. C. 1970 The Joint Venture Process in International Business: India and Pakistan. Cambridge: the MIT Press.

Toyo Keizai. 1995 Kaigai Shinshutsu Kigyo Soran
(Japanese Overseas Investments): Listed by Countries. Tokyo: Toyo Keizai Inc.

Toyo Keizai. 1995 Kaigai Shinshutsu Kigyo Soran (Japanese Overseas Investments): Listed by Firms. Tokyo: Toyo Keizai Inc.

Vernon, R. 1983 Organizational and Institutional Responses to International Risk, in Herring, R. J. (ed.). Managing International Risk. Cambridge: Cambridge University Press.

Woodcock, C. P., Beamish, P. W. and Makino, S. 1994 Ownership-Based Entry Mode Strategies and International Performance. Journal of International Business Studies, 2, 253-273.

(平成11年 3 月 25 日受稿, 平成 11 年 4 月 27 日受理) 
Performance of Japanese Overseas Subsidiaries:

Appendix 1 Summarized Statistics of Variables in the Regression Model

a) Descriptive Statistics of Variables in the regression model

\begin{tabular}{lrccc}
\hline \hline Variables & Mean & Std. Dev. & Max & Min \\
\hline SIZE (logarithm) & 26.22 & 1.41 & 28.81 & 23.58 \\
ADINTEN (ratio) & 1.08 & 2.58 & 23.91 & 0.01 \\
ADINTEN (ratio) & 4.00 & 4.96 & 46.73 & 0.02 \\
EFFICNT (ratio) & 2.60 & 1.80 & 13.41 & 0.55 \\
PROFIT (ratio) & 1.41 & 2.39 & 9.13 & -6.26 \\
INTER & 18.85 & 17.13 & 80 & 1 \\
LOCAL (years) & 23.79 & 18.18 & 87 & 3 \\
SUBEXP (years) & 12.02 & 8.80 & 33 & 3 \\
LOCAL* SUBEXP & 353.19 & 424.24 & 2176.00 & 9.00 \\
MODE & 0.19 & 0.39 & 1 & 0 \\
IJV 1 & 0.19 & 0.42 & 1 & 0 \\
IJV 2 & 0.30 & 0.46 & 1 & 0 \\
ROA (ratio) & 8.36 & 8.54 & 32.50 & -13.70 \\
\hline
\end{tabular}

b) Correlation Matrix of Independent Variables in the regression model

\begin{tabular}{|c|c|c|c|c|c|c|c|c|c|c|c|c|}
\hline Variable & 1 & 2 & 3 & 4 & 5 & 6 & 7 & 8 & 9 & 10 & 11 & 12 \\
\hline 1. SIZE & 1 & & & & & & & & & & & \\
\hline 2. ADINTEN & -.044 & 1 & & & & & & & & & & \\
\hline 3. RDINTEN & .353 & -.019 & 1 & & & & & & & & & \\
\hline 4. EFFICNT & .129 & -.063 & -.079 & 1 & & & & & & & & \\
\hline 5. PROFIT & -.028 & .356 & .092 & -.420 & 1 & & & & & & & \\
\hline 6. INTER & .611 & -.086 & .325 & -.060 & .036 & 1 & & & & & & \\
\hline 7. LOCAL & .278 & -.134 & .083 & -.204 & .016 & .468 & 1 & & & & & \\
\hline 8. SUBEXP & .124 & .045 & .044 & -.091 & -.075 & .164 & .424 & 1 & & & & \\
\hline 9. LOCAL* SUBEXP & .178 & -.032 & .062 & -.098 & -.127 & .309 & .746 & .835 & 1 & & & \\
\hline 10. MODE & -.057 & .117 & .210 & -.170 & .121 & .179 & .016 & -.317 & -.206 & 1 & & \\
\hline 11. IJV 1 & -.038 & .010 & -.071 & .218 & -.081 & .004 & -.077 & -.056 & -.051 & -.235 & 1 & \\
\hline 12. IJV 2 & -.018 & -.058 & -.109 & .036 & -.105 & -.117 & .007 & .180 & .148 & -.321 & -.321 & 1 \\
\hline
\end{tabular}

Appendix 2 Regression Result for Subsidiaries with Single Japanese Parent.

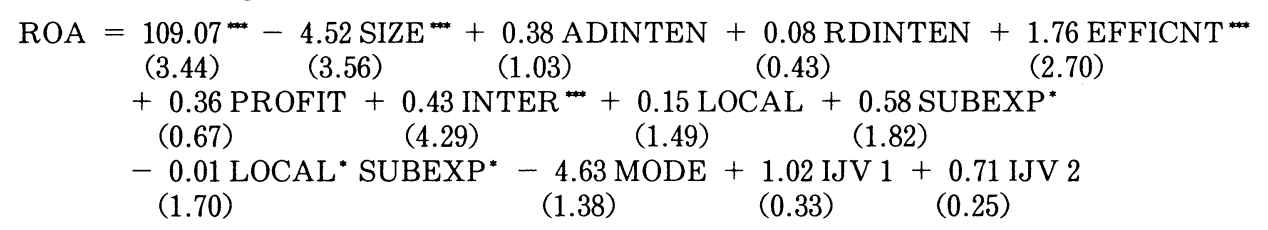

No. of cases $=62$

Model $\mathrm{R}^{2}=0.40$, adjusted $\mathrm{R}^{2}=0.25$

Model significant: $\mathrm{F}=2.73, \mathrm{p}=0.007$

Note: 1) Due to the insignificance of industry effect in this sample, industry variables were not included in the model.

2 ) t-statistics in parentheses; "significant at the $10 \%$ level, "significant at the $5 \%$ level, and "significant at the $1 \%$ level. 
Appendix 3 List of the 190 Japanese subsidiaries used in the empirical study

\begin{tabular}{|c|c|c|c|}
\hline 3TM Plastics & Kao Industrial & Siam IKK & Thai Nylon \\
\hline Aderans Thai & Kitz & Siam Kubota Industry & Thai Otsuka \\
\hline Ajinomoto & Lion Containers & Siam NGK Sparkplug & Pharmaceutical \\
\hline Aoyama Thai & Lion Corp & Siam Okamura Steel & Thai Parkerizing \\
\hline Apple Film & Lion Health Products & Siam Resin and Chemical & Thai QP \\
\hline ARS Chemical & Mahajak International & Siam Riken Industry & Thai Refrigeration \\
\hline Art Serina Piston & Electric & Siam Sanitary Fittings & Components \\
\hline Asahi Electronics & Matsushita Electric Works & Siam Sanitary Ware & Thai Safety Glass \\
\hline Asahi Somboon & Melco Consumer Products & Siam Textile Chemical & Thai Seisen \\
\hline Aluminium & Melco Manufacturing & $\operatorname{SIK}$ & Thai Special Wire \\
\hline Asain Stanley Intl & Thailand & Sony Magnetic Products & Thai Sports Garment \\
\hline Asia Modified Starch & MHI Mahajak Air- & Sony Siam Industry & Thai Staflex \\
\hline Asia Parawood & Conditioners & Strapack & Thai Steel Pipe Industry \\
\hline Asian Autoparts & Minebea Electronics & Sukosol and Mazda Motor & Thai Sumilox \\
\hline Awaji Sangyo & Mitsubishi Elevator Asia & Industry & Thai Suzuki Motors \\
\hline Bangkok Coil Center & Mitsuboshi Belting & Surapon Nichirei Foods & Thai Tabuchi Electric \\
\hline Bangkok Float Glass & Mitsui Toatsu Chemicals & Takeda Chemie Thai & Thai Textile Development \\
\hline Bangkok Foam & Mizuki Electronics & Takeda Thailand & and Finishing \\
\hline Bangkok Metal Industry & MMC Sittipol & Techno Foam & Thai Toray Textile Mills \\
\hline Bangkok Telecom & MMP Packing Group & Teijin Polyester & Public \\
\hline Bijoux Holding Public & Muramoto Electron & Thai-Asahi Glass & Thai Toshiba Electric \\
\hline Cemedine & Musashi Auto Parts & Thai Arrow Products & Industry \\
\hline Central Metals & N\&N Foods & Thai Auto Works & Thai Tricot \\
\hline Century Inoac & National Thai & Thai Benkan & Thai Wacoal Public \\
\hline Cheena Gasket & Nippon Denso & Thai Bridgestone & Thai Wakatsuki \\
\hline Crown Seal & Nippon Paint & Thai Compressor & International \\
\hline Daihen Thailand & Nissan Diesel & Manufacturing & Thai Wire and Cable \\
\hline Dainichi Color Thailand & Nissin Electric & Thai Copper Rod & Service \\
\hline Dainippon Ink and & NMB Hi-Tech Bearing & Thai CRT & Thai Wool Industries \\
\hline Chemicals & NMB Precision Balls & Thai Ferrite & Thai Yamaki \\
\hline Alcast & NMB Thai & Thai Filament Textiles & Thai Yamazaki \\
\hline Data Products Toppan & Ogihara & Thai Foods International & Thai Yazaki Electric Wire \\
\hline Moore & Oriental Electric Industry & Thai Fuji Latex & THASCO Chemical \\
\hline Dia Resibon & Pacific Industries & Thai Fukoku & Tokai Dyeing \\
\hline Diaglas & PCTT & Thai Glico & Top Tube Manufacturing \\
\hline Dusit Textile & Peony Blanket Industry & Thai Hamilton & Toray Nylon Thai \\
\hline Dyna Metal & President Myojo Foods & Thai Honda & TORC \\
\hline Ekarat-Daihen & Riken & Manufacturing & Tostem Thai \\
\hline Transformer & ROHM Apollo & Thai Itokin & Toyo-Toa Coating \\
\hline Erawan Textile & Electronics & Thai Janome & Toyo Ink \\
\hline FCC & Seikosha & Thai Kamaya & Toyo Valve \\
\hline FDK Tatung & Sharp Appliances & Thai Kansai Paint & Toyota Auto Body \\
\hline Fujikura & Shinano Kenshi & Thai Kawasumi & Toyota Motor Thailand \\
\hline Fujitsu & Shindengen & Thai Kodama & TRW Fuji Serina \\
\hline Furukawa Metal & Siam Asahi Technoglass & Thai Koito & TTK Thailand \\
\hline Gochu Chemical & Siam Chemical Industry & Thai Kurabo & Union Autoparts \\
\hline Hitachi Bangkok Cable & Siam Chitose & Thai Lotte & Manufacturing \\
\hline Hoechst Chemical & Siam Chuo Build Industry & Thai Meiji Pharmaceutical & Union Tomita \\
\hline Industries & Siam Compressor & Thai Metal Processing & Union Zojirushi \\
\hline Hymold & Industry & Thai Nippon Concrete & Yakult \\
\hline Isuzu Engine & Siam Electric Industries & Thai Nisca & Yamaken Apparel \\
\hline Manufacturing & Siam Fine Chemicals & Thai Nisshin Seifun & Yanmar SP \\
\hline Jibuhin & Siam GS Battery & Thai NOK & YKK Zipper \\
\hline
\end{tabular}

